\title{
A linear programming model to optimize diets in environmental policy scenarios
}

\author{
L. E. Moraes, ${ }^{*}$ J. E. Wilen, † P. H. Robinson, ${ }^{*}$ and J. G. Fadel ${ }^{{ }^{1}}$ \\ *Department of Animal Science, and \\ †Department of Agricultural and Resource Economics, University of California, Davis 95616
}

\begin{abstract}
The objective was to develop a linear programming model to formulate diets for dairy cattle when environmental policies are present and to examine effects of these policies on diet formulation and dairy cattle nitrogen and mineral excretions as well as methane emissions. The model was developed as a minimum cost diet model. Two types of environmental policies were examined: a tax and a constraint on methane emissions. A tax was incorporated to simulate a greenhouse gas emissions tax policy, and prices of carbon credits in the current carbon markets were attributed to the methane production variable. Three independent runs were made, using carbon dioxide equivalent prices of $\$ 5, \$ 17$, and $\$ 250 /$ t. A constraint was incorporated into the model to simulate the second type of environmental policy, reducing methane emissions by predetermined amounts. The linear programming formulation of this second alternative enabled the calculation of marginal costs of reducing methane emissions. Methane emission and manure production by dairy cows were calculated according to published equations, and nitrogen and mineral excretions were calculated by mass conservation laws. Results were compared with respect to the values generated by a base least-cost model. Current prices of the carbon credit market did not appear onerous enough to have a substantive incentive effect in reducing methane emissions and altering diet costs of our hypothetical dairy herd. However, when emissions of methane were assumed to be reduced by 5, 10, and $13.5 \%$ from the base model, total diet costs increased by $5,19.1$, and $48.5 \%$, respectively. Either these increased costs would be passed onto the consumer or dairy producers would go out of business. Nitrogen and potassium excretions were increased by 16.5 and $16.7 \%$ with a $13.5 \%$ reduction in methane emissions from the base model. Imposing methane restrictions would further increase the demand for grains and other
\end{abstract}

Received June 23, 2011.

Accepted November 7, 2011.

${ }^{1}$ Corresponding author: jgfadel@ucdavis.edu human-edible crops, which is not a progressive solution for an industry trying to be sustainable. However, these results might depend on the constraints and inputs used in our model (e.g., feed prices), and more extensive analyses are required before they are used in policy development. The model structure was able to incorporate effects of environmental policies in diet formulation and it can assist dairy producers in meeting limits set by these policies. The model can also assist policy makers examining the effects of policies on the dairy production system.

Key words: linear programming, diet formulation, environment, policy

\section{INTRODUCTION}

The environmental impact of agriculture has become an important concern for our society. Greenhouse gas (GHG) emissions and nitrate and mineral contamination of water sources have been reported as negative aspects of livestock production (Tamminga, 1992). According to the US Environmental Protection Agency (EPA), in 2009, agriculture was responsible for $6.3 \%$ of total US GHG emissions, and methane $\left(\mathrm{CH}_{4}\right)$ emissions from enteric fermentation represented approximately $20 \%$ of total $\mathrm{CH}_{4}$ emissions from anthropogenic sources (EPA, 2011). These proportions are even larger in developing countries, such as Brazil, in which $\mathrm{CH}_{4}$ from enteric fermentation accounted for approximately $72 \%$ of the country's total emitted $\mathrm{CH}_{4}$ in 1994 (FAO, 2006; Cerri et al., 2009). However, an increase in food production is expected to follow the increase in global food demand, likely requiring an increase in production of animal products. In this context, the amount of environmental impact generated per unit of animal protein produced is an important index of production system sustainability, and system manipulation could be an effective tool to decrease environmental impact. In the last $60 \mathrm{yr}$, environmental impact per unit of milk produced has decreased drastically (Capper et al., 2009) due to genetic improvements of dairy cattle and a better understanding of animal nutrient requirements and efficiency of feed utilization. Methane produc- 
tion in the rumen is mainly a result of carbohydrate fermentation. Nitrogen excretion is related to dietary supply and animal requirement, because digestible (or absorbed) dietary supply above the animal requirement is largely excreted in urine. Therefore, precise diet formulation and balance are required to meet animal nutrient requirements and to decrease the environmental impacts of animal agriculture.

In the late 20th century, numerous feeding systems were developed to establish animal nutrient requirements and composition of feeds (e.g., INRA, 1989; CSIRO, 1990; AFRC, 1993; NRC, 2001). A better understanding of nutrient requirements for animal maintenance and production functions, and division of feeds according to nutrient availability and digestibility has led to a more specific and precise diet formulation. Along with the improvement in establishment of animal nutrient requirements, several studies have been conducted to determine and predict $\mathrm{CH}_{4}$ emissions by cattle (Moe and Tyrrell, 1979; Ellis et al., 2007; Kebreab et al., 2008) as well as manure nitrogen and mineral excretion (Morse et al., 1992; James et al., 1999; Kebreab et al., 2005; Nennich et al., 2005). Several mathematical and statistical models have been developed to predict environmental impact of different animal classes to establish relationships between diet nutrients and the amount of nutrients in products or excreted. Use of such models within a feeding system could enable development of diet optimization models to predict, and minimize, potential environmental impacts using diet cost and animal requirement information.

Dietary manipulation may play an important role in reducing GHG emissions and mineral excretion in the future (Kebreab et al., 2010). Several studies have shown that the type of carbohydrate fermented in the rumen alters $\mathrm{CH}_{4}$ emissions (Moe and Tyrrell, 1979; Beever et al., 1989), with an increase in $\mathrm{CH}_{4}$ emissions per unit of milk produced with increased consumption of structural carbohydrates. Therefore, a reduction in $\mathrm{CH}_{4}$ emissions by dairy cattle, per unit of milk produced, could be achieved with a reduction in fiber and forage intake, because forages usually have a high fiber content. However, reducing the levels of dietary fiber and forage in the diet could lead to selection of feeds with higher contents of protein, starch, and minerals, which can increase animal nitrogen and mineral intake, and excretion, if these nutrients are fed above the animal requirement level.

New policies and legislation are being formulated to limit environmental impacts of livestock production systems. The EPA has issued amendments to the Clean Water Act (US EPA, 2003) to decrease mineral leaching from cattle manure. Concentrated animal feeding op- erations (CAFO) in California are required to develop a nutrient standard plan, and manure produced should be applied to crops and pastures at a level balanced to the nutrient extraction capacity of the plants. Several countries have signed the Kyoto Protocol, a tentative pact in which some countries have agreed to reduce greenhouse gas emissions to a levels equivalent to those of 1990. Carbon markets have experienced increasing activity in Europe (European Union Emission Trading Scheme) and in the last few years, a voluntary carbon market started with its first trading in the United States (Chicago Climate Exchange). The Intergovernmental Panel on Climate Change has developed several prediction and simulation models to account for livestock GHG emissions, and mandatory carbon emission policies could be adopted by several countries in the near future.

Environmental policies are a subject of great discussion, especially the debate between the approaches used to mitigate GHG. Two main policy instruments that motivate GHG reductions have been extensively discussed (Weitzman, 1974); namely, limiting the quantity emitted by a firm or requiring the firm to pay emissions taxes on the amounts emitted. In principle, one can derive a tax that achieves any desired mandated emissions reduction target. A third policy that has been extensively discussed is the cap-and-trade system, which combines features of an emissions limit and emissions tax. Cap-and-trade programs have been used to reduce sulfur dioxide in the US Acid Rain Program and to reduce $\mathrm{NO}_{\mathrm{X}}$ in the Budget Trading Program, both of which are applied to power plant emissions. In capand-trade programs, the overall quantity of emissions is capped by the establishment of emission permits or allowances. Then, individual permits are traded between program participants and this establishes a price for residual emissions. Permits gravitate from those most efficient at reducing emissions to those for whom reductions are costly, ensuring that the aggregate emission reductions are achieved at the lowest overall cost.

In this context, the overall objective of our study was to develop and solve a linear programming model to optimize diets in an environmental policy-driven future scenario. The specific objectives were to develop a model that could examine changes in $\mathrm{CH}_{4}$ emissions and mineral and $\mathrm{N}$ excretion by dairy cattle, associated with adoption of environmental GHG mitigation policies; to examine changes in diet cost and feed selection for diet formulation in such an environmental policy scenario; and to create a mathematical tool to facilitate the joint optimization of reductions in $\mathrm{CH}_{4}$ emissions and nitrogen and mineral excretion with diet costs of cattle. 


\section{MATERIALS AND METHODS}

A least-cost diet model (BASEM) was developed and solved, and its results were used as a basis for comparison with the other model results, representing a scenario with no GHG environmental policies. The BASEM decision variables were available feeds associated with their costs. Model constraints were predicted animal nutrient requirements and intake, defined feed limits in the diet, and diet proportions of fiber fractions, CP, and forage. Methane emissions and manure production were predicted from published equations, and nitrogen and mineral excretions were calculated by mass conservation to estimate potential environmental impacts of dairy cattle under this scenario.

A second linear programming model (TAXM) was then developed to minimize diet costs and costs of methane emissions reductions of dairy cattle. The TAXM was developed to examine changes in diet costs and methane emissions and mineral and nitrogen excretions under a hypothetical environmental policy that taxes $\mathrm{CH}_{4}$ emissions directly. Equivalently, the TAXM can be thought of as a model that examines a capand-trade program in which dairy owners are expected to purchase permits in the carbon market at particular prices to emit the $\mathrm{CH}_{4}$ emissions associated with various feeds and mixes. The amount of $\mathrm{CH}_{4}$ produced was calculated by the equation proposed by Ellis et al. (2007).

For the simulation of an emissions tax (or equivalently a cap and trade with a market price for emissions), the TAXM solution chooses feed quantities and mix to minimize the sum of diet costs and total emissions costs, subject to various nutrition constraints. Total emissions costs in the emissions tax policy simulation are the direct costs associated with hypothetical emission tax rates and the increase in diet costs associated with reducing emissions and the associated tax liabilities. The model computes the optimal feed input mix that just balances off the savings in emissions taxes associated with the last unit of emissions reduction with the increase in diet costs necessary to reduce emissions that marginal amount. By raising the hypothetical tax rate, the model generates a solution with lower emissions levels for $\mathrm{CH}_{4}$, achieved at higher diet feed costs. We chose particular emissions tax rates based on a representation of the carbon credit market. In this scenario, dairy producers are assumed to be required to purchase carbon credits in the carbon credit market (CCX, 2010; ECX, 2010) at levels sufficient to cover their carbon emissions. The TAXM constraint equations were the same equations as in BASEM, being constraints of diet formulation. Methane emissions, and mineral and $\mathrm{N}$ excretions, were predicted and calculated to represent potential environmental impacts of dairy cattle in this scenario.

Finally, a third linear programming model (REDM) was developed to examine changes in diet costs and nitrogen and mineral excretions, under the assumption that dairy producers are required to reduce $\mathrm{CH}_{4}$ emissions by a predetermined amount. Objective function decision variables and model constraints were the same as used in BASEM, but with a constraint to limit emissions of $\mathrm{CH}_{4}$ based on a hypothetical environmental policy. Methane emissions and mineral and N excretions were also predicted and calculated to estimate overall dairy herd potential environmental impacts.

The principal objective of the study was to develop and solve a model capable of formulating least cost diets and assessing potential environmental impacts of dairy cattle under various regulatory scenarios. Development of the model structure could assist in studying environmental policy impacts and assist dairy producers meet demands set by these policies. The model structure is flexible, and available feeds, their costs, animal nutrient requirements, and all prediction equations can be changed according to system characteristics. The model can be applied to any herd size and composition because the constraint equation right hand sizes (i.e., the part of the equation on the right side of the operator) can be scaled according to operation size. The model can also be used in analyses of environmental policies, for example by examining the sensitivity of mineral and nitrogen excretion to reductions of $\mathrm{CH}_{4}$ emissions. Effects of regulatory policies that restrict one class of environmental impacts in one medium (e.g., $\mathrm{CH}_{4}$ emissions) but then cause impacts in other media (e.g., N and mineral excretion) can also be further studied using this model.

\section{General Description of the Model}

The model was developed to minimize diet costs and methane emissions and assess nitrogen and mineral excretions of a dairy cattle herd using the CPLEX solver of the general algebraic modeling system (GAMS) software (Brooke et al., 2008). Seven animal categories were considered to represent a hypothetical dairy herd (Table 1); namely, 3 classes of heifers $(150,300$, and 450 $\mathrm{kg}$ of BW), 2 groups of high-producing cows (primiparous and multiparous) in early lactation, 1 group of mid to late lactation cows, and nonlactating cows. We assumed that calves were sent to an offsite heifer facility at birth and returned after weaning; thus, the herd included no preweaning calves. Diets were formulated to meet the animal daily nutrient requirements and, as the timeframe for the models was $1 \mathrm{~d}$, the herd composition was fixed (i.e., no animals were sold or bought). One 
diet was formulated for each animal category, but the model was optimized over the entire herd of 1,000 animals. The hypothetical herd was composed of $45 \%$ heifers, $5 \%$ nonlactating cows, $8.3 \%$ primiparous lactating cows in the high-producing group, $16.7 \%$ multiparous cows in the high-producing group, and $25 \%$ mid-late lactating cows, in which primiparous and multiparous cows were fed together. Nutrient requirements for the 7 animal categories were calculated using the NRC (2001) model and represent the daily nutrient requirements of this hypothetical dairy herd. Feeds used in diet formulation (Table 2) and their nutrient compositions were also from NRC (2001). The amounts of $\mathrm{CH}_{4}$ produced through rumen enteric fermentation, as well as manure production, were predicted using published linear empirical equations (Nennich et al., 2005; Ellis et al., 2007). Nitrogen and mineral (P, K, and Na) excretions were calculated by mass conservation.

\section{Objective Functions}

The first base model (BASEM) minimizes diet cost, and its results were used as a basis of comparison for the other optimizations. The TAXM model minimizes the sum of diet and $\mathrm{CH}_{4}$ emissions costs, calculating emissions costs as tax (or the carbon credit market price) associated with the $\mathrm{CH}_{4}$ emissions level. The REDM model also minimizes diet costs and has a constraint equation to reduce $\mathrm{CH}_{4}$ emissions by pre-determined amounts. The BASEM and REDM objective functions (equation [1]), which minimize diet costs $\left(\mathrm{COST}_{\mathrm{BASEM}}\right.$ and $\operatorname{COST}_{\text {REDM }}$ ), are identical:

$$
\text { Minimize } \operatorname{COST}_{\mathrm{BASEM}, \mathrm{REDM}}=\sum_{a=1}^{7} \sum_{j=1}^{19} x_{j a} c_{j},
$$

where $x_{j a}$ is the amount ( $\mathrm{kg}$ of $\mathrm{DM}$ ) of feed $j$ for animal category $a$, and $c_{j}$ is the cost $(\$ / \mathrm{kg}$ of $\mathrm{DM})$ of feed $j$.
The TAXM objective function (equation [2]) minimizes diet and $\mathrm{CH}_{4}$ emission costs:

$$
\text { Minimize } \operatorname{COST}_{\mathrm{TAXM}}=\sum_{a=1}^{7} \sum_{j=1}^{19} x_{j a} c_{j}+\sum_{a=1}^{7} e_{a} p,
$$

where $x_{j a}$ is the amount ( $\mathrm{kg}$ of DM) of feed $j$ for animal category $a, c_{j}$ is the cost $\left(\$ / \mathrm{kg}\right.$ of DM) of feed $j, e_{a}$ is the amount of $\mathrm{CH}_{4}$ emitted (t) by animal category $a$, and $p$ is the fixed cost of $\mathrm{CH}_{4}$ emission $(\$ / \mathrm{t})$, based on the carbon credit market (Edmonds et al., 1997; CCX, 2010; ECX, 2010). A radiation reflection potential of 21 times the $\mathrm{CO}_{2}$ potential for $\mathrm{CH}_{4}$ (IPCC, 1996) was assumed; that is, the cost of the $\mathrm{CH}_{4}$ tonne was assumed to be 21 times the cost of the $\mathrm{CO}_{2}$-equivalent tonne. The energetic content of $\mathrm{CH}_{4}$ was assumed to be $55.65 \mathrm{MJ} / \mathrm{kg}$ of $\mathrm{CH}_{4}$ (IPCC, 1996) because $\mathrm{CH}_{4}$ was calculated in megajoules in the prediction equation.

Feed prices were extracted from the Pennsylvania State University feed price list (Penn State Feed Price List, 2011) and are in Table 2. The Penn State Feed price list was used due to its large number of feeds. The prices for the 4 mineral sources were collected locally in California and are also given in Table 2. Three roughage sources are given in Table 2 and, for the purposes of this paper, all other commodities were considered concentrates. Methane production was calculated using the equation of Ellis et al. (2007), relating $\mathrm{CH}_{4}$ emissions to NDF and ME intakes. In TAXM, the cost of emitting $\mathrm{CH}_{4}$ was assumed equal to the cost of acquiring carbon credits in the carbon market, representing a potential scenario in which dairy producers would be required to purchase carbon credits equal to emissions. Effects of $\mathrm{CH}_{4}$ costs on diet costs and environmental impacts were examined by utilizing 3 optimizations for TAXM; namely, $\mathrm{CH}_{4}$ costs of $\$ 5, \$ 17$, and $\$ 250 / \mathrm{CO}_{2}$-equivalent tonne, with $\$ 5 / \mathrm{t}$ cost representing a scenario with the current US carbon allowance price (CCX, 2010), the

Table 1. Description of the 1,000-animal hypothetical herd used in model optimizations

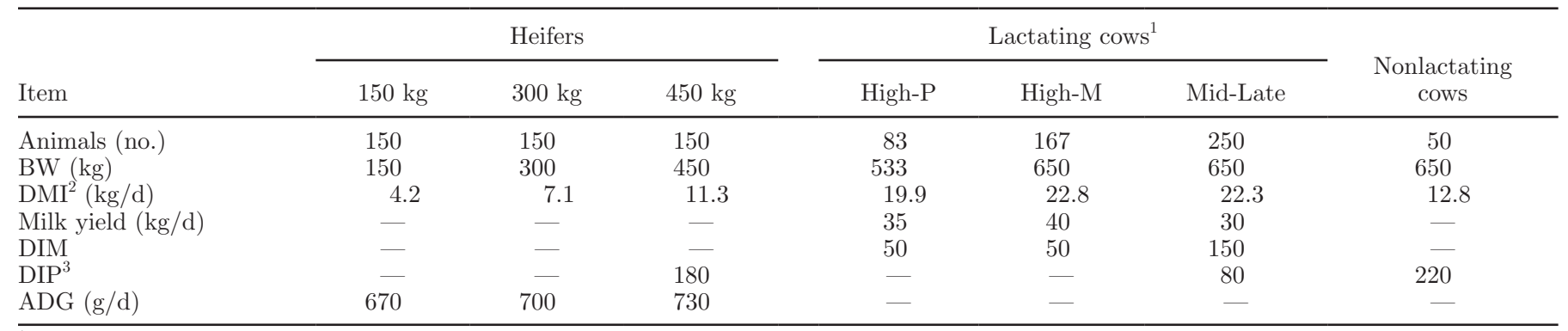

${ }^{1}$ High-P = high-producing primiparous lactating cow group; High-M = high-producing multiparous lactating cow group; Mid-Late = mid and late lactating cow group.

${ }^{2} \mathrm{DMI}$ used as maximum intakes in model constraints.

${ }^{3}$ Days in pregnancy. 
Table 2. Dietary feed upper limits and feed costs

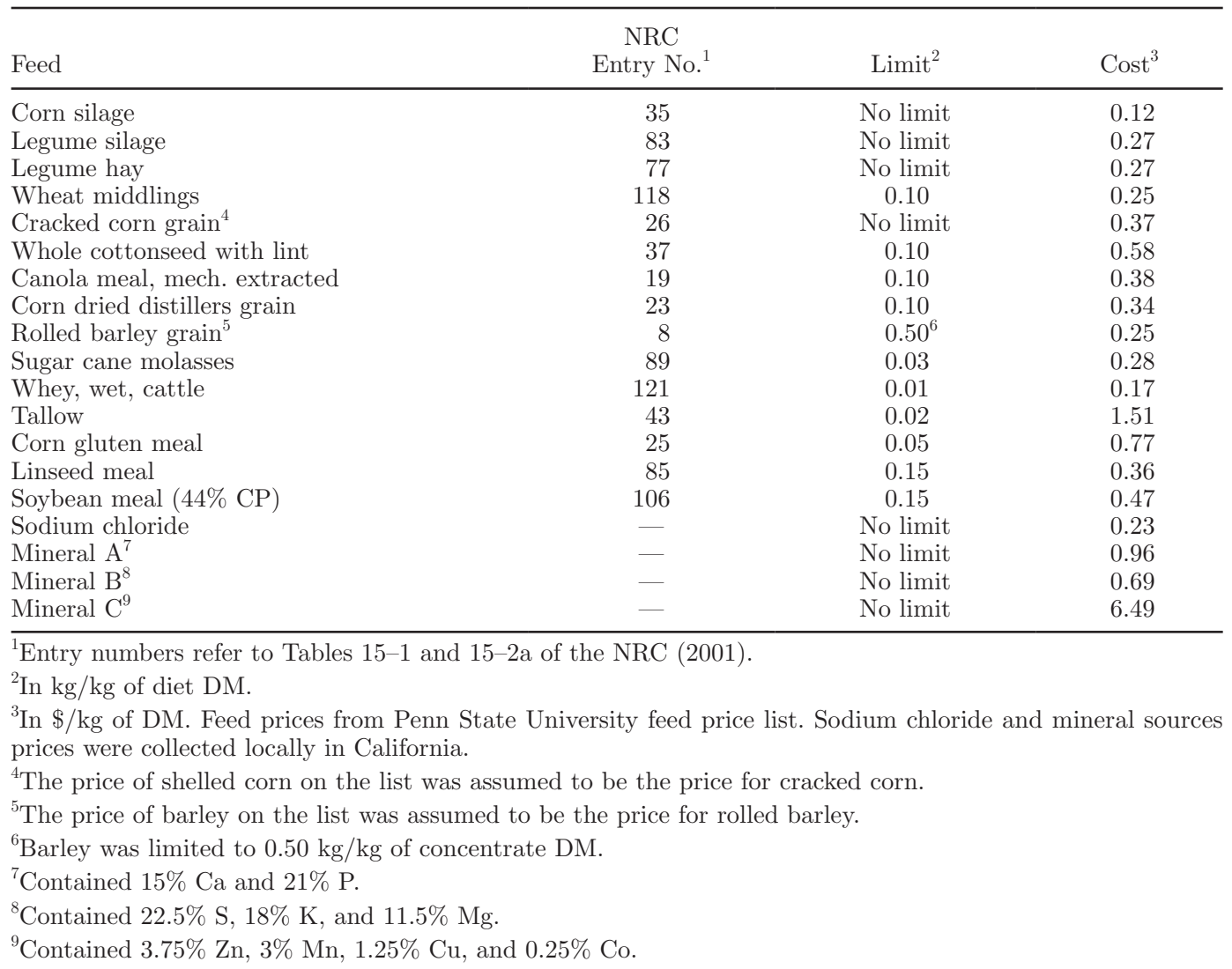

$\$ 17 / \mathrm{t}$ cost representing a scenario with the current European carbon allowance price (ECX, 2010), and the $\$ 250 / t$ cost being one of the carbon credit prices estimated by Edmonds et al. (1997) if the United States is determined to reduce emissions by the amount stated in the Kyoto Protocol.

\section{Constraint Equations}

Model constraint equations were used to set animal minimum nutrient requirements (equation [3]), maximum DMI (equation [4]), upper limits of feeds in the diet (equations [5] and [6]), and nutrient restrictions (equations [7] and [8]), which included minimum and maximum proportions of $\mathrm{NDF}, \mathrm{ADF}$, and $\mathrm{CP}$ in the diet. Forage dietary proportion was also limited to a predetermined range (equation [9]). The same constraint equations were used for the 3 models, making the decision variable values comparable among models, except for the $\mathrm{CH}_{4}$ emission constraint in REDM.The right hand side of constraint equations [3] and [4] represented values for the total animal category. These values were then divided by the number of animals in each category so that results could be expressed on a herd and animal basis.
Nutrient Requirements. Nutrient requirements and DMI were calculated for each animal category according the NRC (2001) model. Energy requirements were calculated on an ME basis for heifers and on an $\mathrm{NE}_{\mathrm{L}}$ basis for cows. Protein requirements were calculated as RDP and RUP amounts. The DM intake predicted by the NRC (2001) model was used to calculate rates of passage $\left(\mathbf{k}_{\mathrm{p}}\right)$ for each feed consumed by each animal category. These rates were then used along with rates of digestion $\left(\mathbf{k}_{\mathrm{d}}\right)$ of the $\mathrm{CP}$ "B" fraction (i.e., potentially degradable $\mathrm{CP}$ ), from the NRC (2001), to calculate RDP and RUP contents of the feeds. Requirements for RDP were set as 1.18 times microbial CP production. Microbial CP conversion to MP was set as 0.64 , and RUP digestibility values were used according the NRC (2001). Feed $\mathrm{ME}$ and $\mathrm{NE}_{\mathrm{L}}$ contents are dependent on DMI because discount factors are used to represent a decrease in feed digestibility with increasing levels of intake above maintenance. Furthermore, RDP and RUP are also dependent on DMI because the equations used by the NRC (2001) to calculate these 2 protein values are dependent on $k_{p}$. Therefore, the feed composition matrix calculated using the predicted DMI might not reflect the nutrient composition of feeds at the model solution intake level. To ensure that protein and 
energy requirements are met, an iterative process was used in which the feed composition matrix was updated according to the actual intake at the model solution and the model was re-solved. The process was repeated until a stable solution was found; that is, the DMI and concentrate proportions of the diet were relatively constant in the final linear program. Animal requirements of RDP and RUP are also dependent on intake and dietary composition because $\mathrm{RDP}$ requirements are calculated from efficiency of microbial protein usage and microbial protein production, which is calculated from total digestible nutrients intake. Therefore, to ensure that RDP and RUP requirements were met, these requirements were also updated in the iterative method described before, based on actual intake and dietary composition. Mineral requirements (i.e., Ca, P, K, S, $\mathrm{Na}, \mathrm{Mg}, \mathrm{Cl}, \mathrm{Zn}, \mathrm{Fe}, \mathrm{Mn}, \mathrm{Cu}$ ) were calculated according the NRC (2001). To minimize excess mineral feeding, 4 mineral sources were used (Table 2) as possible feeds in the linear program model, as discussed later. The nutrient requirement constraint equation is represented by

$$
\sum_{j=1}^{19} x_{j a} n_{i j} \geq b_{i a},
$$

where $x_{j a}$ is the amount of feed $j(\mathrm{~kg}$ of DM) for animal category $a, n_{i j}$ is the nutrient $i$ content (MJ, g, or mg/ $\mathrm{kg}$ of $\mathrm{DM}$ ) of feed $j$, and $b_{i a}$ is the animal requirement of nutrient (MJ, g, or $\mathrm{mg}$ ) $i$ for animal category $a$. The recursive equation [3] generated 98 constraint equations representing 7 animal categories $(a=1$ to 7$)$ and 14 nutrients $(i=1$ to 14$)$.

DMI. Dry matter intake for each animal category was calculated using the NRC (2001) model and was set as the maximum DMI constraint for each animal category:

$$
\sum_{j=1}^{19} x_{j a} \leq y_{a}
$$

where $x_{j a}$ is the amount of feed $j(\mathrm{~kg}$ of DM) for animal category $a$, and $y_{a}$ is the maximum DMI ( $\mathrm{kg}$ of DM) for animal category $a$, for 7 animal categories ( $a=1$ to 7 ), generating 7 constraint equations.

Dietary Feed Limits. Upper dietary feed limits were the same for all animal categories, on a DM basis. Whole cottonseed, wheat middlings, dried corn distillers grains, corn gluten meal, linseed meal, soybean meal, molasses, tallow, whey, and canola meal were limited to a fixed maximum dietary proportion (Table 2), with the constraint equation [5]:

$$
\frac{x_{j a}}{\sum_{j=1}^{19} x_{j a}} \leq l_{j a},
$$

where $x_{j a}$ is the amount of feed $j(\mathrm{~kg}$ of $\mathrm{DM})$ for animal category $a$ and $l_{j a}$ is the limit of feed $j(\mathrm{~kg} / \mathrm{kg} \mathrm{DM})$ in the diet of animal category $a$. The recursive equation [5] generated 70 equations representing 7 animal categories ( $a=1$ to 7 ) and 10 feeds $(j=1$ to 10$)$. Equation [5] was rearranged so it could be expressed in a linear form, multiplying $l_{j a}$ by the denominator.

Rolled barley grain was limited to a maximum proportion of $0.50 \mathrm{~kg} / \mathrm{kg}$ of the concentrate DM with the constraint equation [6]:

$$
\frac{b a r_{a}}{\sum_{j^{\prime}=1}^{16} x_{j^{\prime} a}} \leq m b a r_{a},
$$

where $b_{a r}$ is the amount of rolled grain barley $(\mathrm{kg}$ of DM) for animal category $a, x_{j^{\prime} a}$ is the amount of concentrate $j^{\prime}\left(\mathrm{kg}\right.$ of DM) for animal category $a$, and mbar $_{a}$ is the maximum proportion of rolled grain barley in the dietary concentrate of animal category $a(\mathrm{~kg} / \mathrm{kg}$ of DM). Note that $x_{j^{\prime} a}$ represents the subset of $x_{j a}$ that are concentrates (16 feeds). The recursive equation [6] generated 7 equations representing diets of 7 animal categories $(a=1$ to 7 ). Equation [6] was rearranged so it could be expressed in a linear form by multiplying mbar $_{a}$ by the denominator.

Other Limits. Dietary proportions of NDF, ADF, and $\mathrm{CP}$ were specified with equation [7]. The proportions of NDF and ADF were limited to minimums of 0.25 and $0.17 \mathrm{~kg} / \mathrm{kg}$ of $\mathrm{DM}$ for all animal categories. The maximum proportion of NDF was set as 0.40 and $0.35 \mathrm{~kg} / \mathrm{kg}$ of DM for heifers and nonlactating cows and for lactating cows, respectively. The maximum ADF dietary proportion was set as 0.30 and $0.25 \mathrm{~kg} / \mathrm{kg}$ of DM for heifer and nonlactating cows and for lactating cows, respectively. The $\mathrm{CP}$ was limited to a maximum dietary proportion of $0.20 \mathrm{~kg} / \mathrm{kg}$ of $\mathrm{DM}$ in diets for all animal categories. No minimum CP dietary proportion was specified (i.e., the minimum $\mathrm{CP}$ proportion was set to $0 \mathrm{~kg} / \mathrm{kg}$ of $\mathrm{DM}$ ) because animal minimum protein requirements are specified through RDP and RUP amounts.

$$
u_{t a} \leq \frac{\sum_{j=1}^{19} x_{j a} w_{t j}}{\sum_{j=1}^{19} x_{j a}} \leq q_{t a},
$$


where $x_{j a}$ is the amount of feed $j(\mathrm{~kg}$ of DM) for animal category $a, w_{t j}$ is the nutrient $t$ proportion of feed $j(\mathrm{~kg} /$ $\mathrm{kg}$ of $\mathrm{DM}), u_{t a}$ is the diet minimum proportion of nutrient $t\left(\mathrm{~kg} / \mathrm{kg}\right.$ of DM) for animal category $a$, and $q_{t a}$ is the diet maximum proportion of nutrient $t(\mathrm{~kg} / \mathrm{kg}$ of DM) for animal category $a$. Nutrients here are indexed by $t$ to distinguish nutrients $w_{t j}$ that are used in equations as specific dietary proportions (i.e., NDF, ADF, CP) of total feed from $n_{i j}$ as described in equation [3]. The recursive equation [7] generated 42 constraint equations representing maximum and minimum proportions of 3 nutrients ( $t=1$ to 3 ) and 7 animal categories ( $a=1$ to 7). Equation [7] was rearranged so it could be expressed in a linear form, multiplying either $u_{t a}$ or $q_{t a}$ by the denominator.

The dietary NDF from forage proportion was limited to a minimum of $0.19 \mathrm{~kg} / \mathrm{kg}$ of DM in all diets, with the constraint equation [8]:

$$
\frac{\sum_{j==1}^{3} x_{j^{\prime \prime} a} f_{j "}}{\sum_{j=1}^{19} x_{j a}} \geq d f_{a},
$$

where $x_{j " a}$ is the amount of feed for the $j$ "th forage $(\mathrm{kg}$ of DM), within animal category $a, f_{j}$, is the NDF proportion of forage $j "(\mathrm{~kg} / \mathrm{kg}$ of $\mathrm{DM}), x_{j a}$ is the amount of feed $j\left(\mathrm{~kg}\right.$ of DM) for animal category $a$, and $d f_{a}$ is the minimum dietary proportion of NDF from forage $(\mathrm{kg} / \mathrm{kg}$ of $\mathrm{DM})$ for animal category $a$. Variable $x_{j^{\prime \prime} a}$ is summed from 1 to 3 in the equation numerator to represent the summation of feeds that represent forages. Note that $x_{j \prime a}$ is a subset of $x_{j a}$. The recursive equation [8] generated 7 constraint equations representing dietary proportions of 7 animal categories ( $a=1$ to 7 ). Equation [8] was rearranged so it could be expressed in a linear form by multiplying $d f_{a}$ by the denominator.

Dietary Forage Proportion. The proportion of dietary forage was limited to a minimum value of 0.40 $\mathrm{kg} / \mathrm{kg}$ of DM for all animal categories, to prevent metabolic disorders. The maximum diet forage proportion was set to $0.80 \mathrm{~kg} / \mathrm{kg}$ of DM for nonlactating animals and $0.60 \mathrm{~kg} / \mathrm{kg}$ of DM for lactating animals:

$$
v_{a} \leq \frac{\sum_{j^{\prime \prime}=1}^{3} x_{j^{\prime \prime} a}}{\sum_{j=1}^{19} x_{j a}} \leq d_{a},
$$

where $x_{j " a}$ is the amount of feed for the $j$ "th forage ( $\mathrm{kg}$ of DM), within animal category $a, x_{j a}$ is the amount of the $j$ th feed $(\mathrm{kg}$ of $\mathrm{DM})$ within animal category $a, v_{a}$ is the minimum proportion of diet forage for animal category $a(\mathrm{~kg} / \mathrm{kg}$ of $\mathrm{DM})$, and $d_{a}$ is the maximum proportion of diet forage for animal category $a(\mathrm{~kg} /$ $\mathrm{kg}$ of DM). Variable $x_{j^{\prime \prime} a}$ is summed from 1 to 3 in the equation numerator to represent the summation of feeds that represent forages. Note that $x_{j^{\prime \prime} a}$ is a subset of $x_{j a}$. The recursive equation [9] generated 14 constraint equations representing minimum and maximum dietary forage proportions for 7 animal categories ( $a=1$ to 7 ). Equation [7] was rearranged so it could be expressed in a linear form, multiplying either $v_{a}$ or $d_{a}$ by the denominator.

Methane Restriction. The REDM had a constraint equation to reduce the amount of $\mathrm{CH}_{4}$ emissions by a predetermined amount. This equation (Ellis et al., 2007 ) is the same as that used in BASEM to predict methane emissions and that used in TAXM to calculate the $\mathrm{CH}_{4}$ variable value. The equation was rearranged to form a maximum constraint in which the right hand side was set to proportional reductions of the amount of methane emitted in BASEM. Three runs were made for REDM, reducing the total amount of $\mathrm{CH}_{4}$ emitted by restricting 5,10 , or $13.5 \%$ of the $\mathrm{CH}_{4}$ emitted in BASEM. Results for these 3 runs are presented in tables and in the Appendix as REDM5, REDM10, and REDM13.5. The maximum reduction in $\mathrm{CH}_{4}$ emissions for a feasible solution was $13.5 \%$. The constraint equation for reducing $\mathrm{CH}_{4}$ emissions of REDM is

$$
\sum_{a=1}^{7} \sum_{j=1}^{19} x_{j a} c_{1} N D F_{j}+\sum_{a=1}^{7} \sum_{j=1}^{19} x_{j a} c_{2} M E_{j} \leq A_{T} C H_{4} 1-\mathrm{Int},
$$

where $x_{j a}$ is the amount of feed $j$ ( $\mathrm{kg}$ of DM) for animal category $a, c_{1}\left(\mathrm{MJ} / \mathrm{kg}\right.$ of NDF) and $c_{2}(\mathrm{MJ} / \mathrm{MJ}$ of $\mathrm{ME})$ are the $\mathrm{CH}_{4}$ emission prediction equation (equation [11]) parameters, $N D F_{j}$ is the NDF content $(\mathrm{kg} / \mathrm{kg}$ of $\mathrm{DM})$ of feed $j, M E_{j}$ is the ME content (MJ/kg of DM) of feed $j, A_{T}$ is the amount of reduction determined in the $\mathrm{CH}_{4}$ emission (\%), and $\mathrm{CH}_{4} 1$ is the amount of $\mathrm{CH}_{4}$ (MJ) emitted in BASEM. For the 3 runs of REDM, $A_{T}$ was set to $0.95,0.90$, and 0.865 representing a 5,10 , and $13.5 \%$ reduction in $\mathrm{CH}_{4}$, respectively. Finally, Int is the intercept of the $\mathrm{CH}_{4}$ prediction equation, representing the total herd (equation [11] intercept $\times 1,000$ ).

\section{Methane Emissions and Excretion Calculations}

Equations used to predict methane emissions and manure production (equations [11] to [14]) are in Table 3 . The amount of $\mathrm{CH}_{4}$ produced by the herd was calculated by equation [11]. This equation was used in 
BASEM as a prediction equation, with the function to predict the amount of $\mathrm{CH}_{4}$ produced in a scenario with no environmental GHG policies. Equation [11] was used in TAXM to predict the value of the $\mathrm{CH}_{4}$ variable and in REDM as a constraint equation to restrict the amount of $\mathrm{CH}_{4}$ produced by predetermined amounts, as specified in equation [10]. Manure production equations were used in the 3 models with predictive purposes and were dependent on DMI (equations [12], [13] and [14]). Nitrogen, phosphorus, potassium, and sodium excretions were calculated by mass conservation laws; that is, each element excretion was assumed to be its dietary intake minus the retained amount. The NRC (2001) was used to calculate retained $\mathrm{N}, \mathrm{P}, \mathrm{K}$, and $\mathrm{Na}$ for each animal category, in which the retained amount was assumed to be the sum of retention in growth, milk, and pregnancy. Growth-retained mineral and $\mathrm{N}$ was assumed to be zero in lactating cows. Animals with pregnancy as early as $190 \mathrm{~d}$ are assumed to have no requirement for pregnancy as specified by the NRC (2001) model. Retention of nitrogen in milk was assumed to be $4.8 \mathrm{~g}$ of $\mathrm{N} / \mathrm{kg}$ of milk; that is, $0.03 \mathrm{~kg}$ of $\mathrm{CP} / \mathrm{kg}$ of milk.

\section{RESULTS AND DISCUSSION}

The developed optimization model formulates minimum cost diets and assesses enteric $\mathrm{CH}_{4}$ emissions and mineral excretion of a dairy cattle herd when $\mathrm{CH}_{4}$ emissions are taxed or restricted. The BASEM model represents a base least-cost diet, simulating a scenario with no GHG environmental policies, and its results were used to assess changes in diet costs, diet formulation, and potential environmental impacts of the 2 classes of policies used in TAXM and REDM. The TAXM model was formulated with an assumed tax on $\mathrm{CH}_{4}$ emissions based on carbon allowances, and REDM was formulated to represent a policy that imposes a predetermined reduction in $\mathrm{CH}_{4}$ emissions from a base model. Nitrogen and mineral intakes and excretions and $\mathrm{CH}_{4}$ emissions were calculated to assess overall potential environmental impacts of each scenario. The model was solved with one set of (regional) prices and for a given herd structure at a fixed level of productivity; therefore, results generated with another scheme of model inputs might differ from our results. However, diets and potential environmental impacts are discussed to illustrate results generated by the model structure.

The inclusion of the carbon credit market cost, taxing the $\mathrm{CH}_{4}$ decision variable in TAXM, did not substantially alter $\mathrm{CH}_{4}$ emissions or diet costs because marginal costs of changing the solution vector basis greatly exceeded the tax cost as discussed later in this paper. When $\$ 5$ and $\$ 17 / \mathrm{t}$ costs of $\mathrm{CO}_{2}$ equivalent were used for the $\mathrm{CH}_{4}$ decision variable, diets formulated by TAXM were equal to diets formulated in BASEM, resulting in the same diet costs and $\mathrm{CH}_{4}$ total emissions (i.e., $12,595 \mathrm{MJ}$ or $226 \mathrm{~kg}$ ). When the $\$ 250 / \mathrm{t}$ of $\mathrm{CO}_{2}$ equivalent cost was used, a very small change occurred in diet formulation, increasing diet cost by $0.02 \%$ and reducing total $\mathrm{CH}_{4}$ emissions by only $0.11 \%$. The diets formulated were very similar to diets in BASEM, and mineral and $\mathrm{N}$ excretions, as $\mathrm{CH}_{4}$ emissions and diet costs, were not substantially altered. Therefore, because the results for TAXM are essentially the same as in BASEM, they are presented together as BASEM. The only difference is that the tax portion of the objective function (equation [2]) resulted in an increase of total herd costs by about $\$ 1,188\left[0.227 \mathrm{CH}_{4} \mathrm{t} \cdot(21 \mathrm{t}\right.$ $\mathrm{CO}_{2}$-equivalent $\left.\left./ \mathrm{CH}_{4} \mathrm{t}\right) \cdot\left(\$ 250 / \mathrm{CO}_{2} \mathrm{t}\right)\right]$ over feed costs.

The current carbon credit market prices, and even the high price proposed by Edmonds et al. (1997), would thus have no substantive effect in reducing $\mathrm{CH}_{4}$ emissions of our hypothetical herd if dairy producers were required to purchase carbon credits. This is because the high cost of decreasing $\mathrm{CH}_{4}$ emissions by dietary manipulation exceeds the cost of purchasing $\mathrm{CH}_{4}$ emissions credits, even at relatively high carbon credit market prices. There may be other ways to reduce the amount of $\mathrm{CH}_{4}$ emitted in a dairy production system, with capital investment or other types of feeding efficiency improvements; here we consider only dietary

Table 3. List of equations used to predict methane emissions and manure production

\begin{tabular}{lll}
\hline $\begin{array}{l}\text { Equation } \\
\text { no. }\end{array}$ & Environmental impact & \\
\hline$[11]^{2}$ & $\mathrm{CH}_{4}$ emissions, $\left(\mathrm{CH}_{4}, \mathrm{MJ}\right)$ & Equation \\
{$[12]^{3}$} & Manure excretion, $\left(\mathrm{M}_{\mathrm{E}}, \mathrm{kg}\right)$ & $\mathrm{CH}_{4}(\mathrm{MJ})=0.0224 \times \mathrm{ME}$ intake $(\mathrm{MJ})+0.980 \times \mathrm{NDF}$ intake $(\mathrm{kg})+4.41$ \\
{$[13]^{4}$} & Manure excretion, $\left(\mathrm{M}_{\mathrm{E}}, \mathrm{kg}\right)$ & $\mathrm{M}_{\mathrm{E}}(\mathrm{kg})=\mathrm{DMI}(\mathrm{kg}) \times 3.45$ \\
{$[14]^{5}$} & Manure excretion, $\left(\mathrm{M}_{\mathrm{E}}, \mathrm{kg}\right)$ & $\mathrm{M}_{\mathrm{E}}(\mathrm{kg})=\mathrm{DMI}(\mathrm{kg}) \times 4.158-\mathrm{BW}(\mathrm{kg}) \times 0.0246$ \\
\hline
\end{tabular}

\footnotetext{
${ }^{1}$ Denoted by (dependent variable, unit).

${ }^{2}$ Used for all animal categories. From Ellis et al. (2007).

${ }^{3}$ Used for heifers with 150 and $300 \mathrm{~kg}$ of BW. From Nennich et al. (2005).

${ }^{4}$ Used for heifers with $450 \mathrm{~kg}$ of BW and nonlactating cows. From Nennich et al. (2005).

${ }^{5}$ Used for lactating cows. From Nennich et al. (2005).
} 
manipulation under representative prices and process equations.

The $\mathrm{CH}_{4}$ mitigation cost was also assessed by analysis of shadow prices of REDM, which represent the change in the objective function optimal value when a constraint equation is relaxed or strengthened by 1 unit. For our hypothetical herd, much higher costs of the carbon equivalent allowance would need to be established to reduce $\mathrm{CH}_{4}$ emissions by a tax-based mitigation policy. However, more detailed analyses using the methodology developed in this paper are necessary before these mitigation costs could be extrapolated to a wider range of production costs, because the model results are highly dependent on model inputs.

The 3 runs made for REDM achieved their objectives, as determined by $\mathrm{CH}_{4}$ emissions constraints, in reducing the level of $\mathrm{CH}_{4}$ emitted based upon BASEM by 5,10 , and $13.5 \%$. Feed selection for diet formulation was altered, as well as $\mathrm{CH}_{4}$ emissions and mineral and $\mathrm{N}$ excretions from the herd. Diet costs were increased due to the restriction in $\mathrm{CH}_{4}$ emissions, which reduced model flexibility in finding a new combination of feeds that met all model constraints at minimum cost.

A detailed description of diets formulated by all models is given in the Appendix. Diets formulated by BASEM usually had a higher proportion of forage than diets formulated by REDM because the $\mathrm{CH}_{4}$ emission prediction equation uses NDF intake as an independent variable and, typically, when dietary forage proportion is reduced, dietary NDF is also reduced. Therefore, the reduction of $\mathrm{CH}_{4}$ emissions in REDM was achieved by reducing use of feeds with a high NDF content, which makes biological sense, because $\mathrm{CH}_{4}$ emissions from ruminal fermentation is increased with fermentation of structural carbohydrates. Corn silage was the principal forage used in BASEM diets. However, when $\mathrm{CH}_{4}$ emissions were restricted in REDM at the $13.5 \%$ reduction level, the proportion of corn silage in the diet was reduced and proportions of legume silage were increased. As corn silage has a higher NDF content than legume silage in our set of feeds, legume silage was chosen to replace part of the corn silage in the diets, thereby decreasing the dietary NDF proportion. As corn silage also has high $\mathrm{ME} / \mathrm{NE}_{\mathrm{L}}$ level for forage, its proportional reduction in REDM diets caused other feed energy sources to be used, especially grains and cereal-derived meals. Indeed, cracked corn grain, whole cottonseed, and tallow were included in diets and the proportion of soybean meal was greatly increased at $13.5 \% \mathrm{CH}_{4}$ reduction. The substitution of forages by grains and cereals in livestock diets as a $\mathrm{CH}_{4}$ mitigation strategy might increase the dairy sector demand of human-edible products, increasing the competition between humans and animals for cereal and grains. This increased competi- tion might decrease the supply of grain cereals for human consumption, increasing food prices. On the other hand, if forage energy sources in animal diets are partly substituted with by-products, the utilization of humaninedible products by livestock would be increased, as discussed by Fadel (2010), and the competition between cereal grains between humans and animals might be reduced because land previously used for forage production could be used for food production.

A complete analysis of changes in dietary composition with supposed adoption of environmental policies was possible due to the model structure, which linked feed formulation with minimization of $\mathrm{CH}_{4}$ emissions. As expected, the NDF and ADF contents were lower in REDM compared with BASEM, and the reduction of $\mathrm{CH}_{4}$ emissions of 5,10 , and $13.5 \%$ led to a decrease in dietary NDF (Figure 1) level due to the positive effect of structural carbohydrates on ruminal $\mathrm{CH}_{4}$ production. From a mathematical perspective, the reduction of dietary $\mathrm{NDF}$ and the reduction of DMI were 2 possible ways to reduce $\mathrm{CH}_{4}$ emissions with the model structure adopted because minimum energy requirements were generally binding constraints. When the $13.5 \%$ reduction in $\mathrm{CH}_{4}$ emissions was used as a constraint in REDM, dietary NDF and ADF levels generally fell to the minimum values defined by model fiber constraint equations of 0.25 and $0.17 \mathrm{~kg} / \mathrm{kg}$ of DM, respectively. Thus, these constraints would not allow substantive further reduction in $\mathrm{CH}_{4}$ emissions for most animal categories. The shadow prices of the minimum NDF and ADF proportion constraints (Table 4) increased when $\mathrm{CH}_{4}$ emissions were reduced from 5 to $13.5 \%$ in REDM. The $\mathrm{ME} / \mathrm{NE}_{\mathrm{L}}$ density of diets was generally increased with a reduction in $\mathrm{CH}_{4}$ emissions (Figure 1), because of a decrease in DMI and selection of feeds low in fiber and consequently high in $\mathrm{ME} /$ $\mathrm{NE}_{\mathrm{L}}$. Methane emissions expressed in MJ/100 MJ of ME intake decreased, as expected, with the restriction in $\mathrm{CH}_{4}$ emissions (Table 5) and ranged, among animal groups, from 7.06 to $18.24 \mathrm{MJ} / 100 \mathrm{MJ}$ of ME intake in BASEM and from 6.09 to $16.80 \mathrm{MJ} / 100 \mathrm{MJ}$ of ME intake with a $13.5 \%$ reduction in $\mathrm{CH}_{4}$ emissions in REDM. Dietary CP levels increased with a reduction in $\mathrm{CH}_{4}$ emissions (Figure 1). When the right hand side of the $\mathrm{CH}_{4}$ constraint was set to a $13.5 \%$ reduction, the dietary $\mathrm{CP}$ proportion was usually increased to the maximum value of $0.20 \mathrm{~kg} / \mathrm{kg}$ of $\mathrm{DM}$ allowed by the model CP constraint and the shadow prices for dietary CP maximum constraint increased (Table 4). Thus, when $\mathrm{CH}_{4}$ emissions are restricted, the marginal costs of limiting maximum $\mathrm{CP}$ and minimum $\mathrm{NDF}$ and $\mathrm{ADF}$ levels in the diet increase.

Generally, the 3 runs for REDM (i.e., 5, 10, and $13.5 \%$ reduction of $\mathrm{CH}_{4}$ emissions from BASEM) 

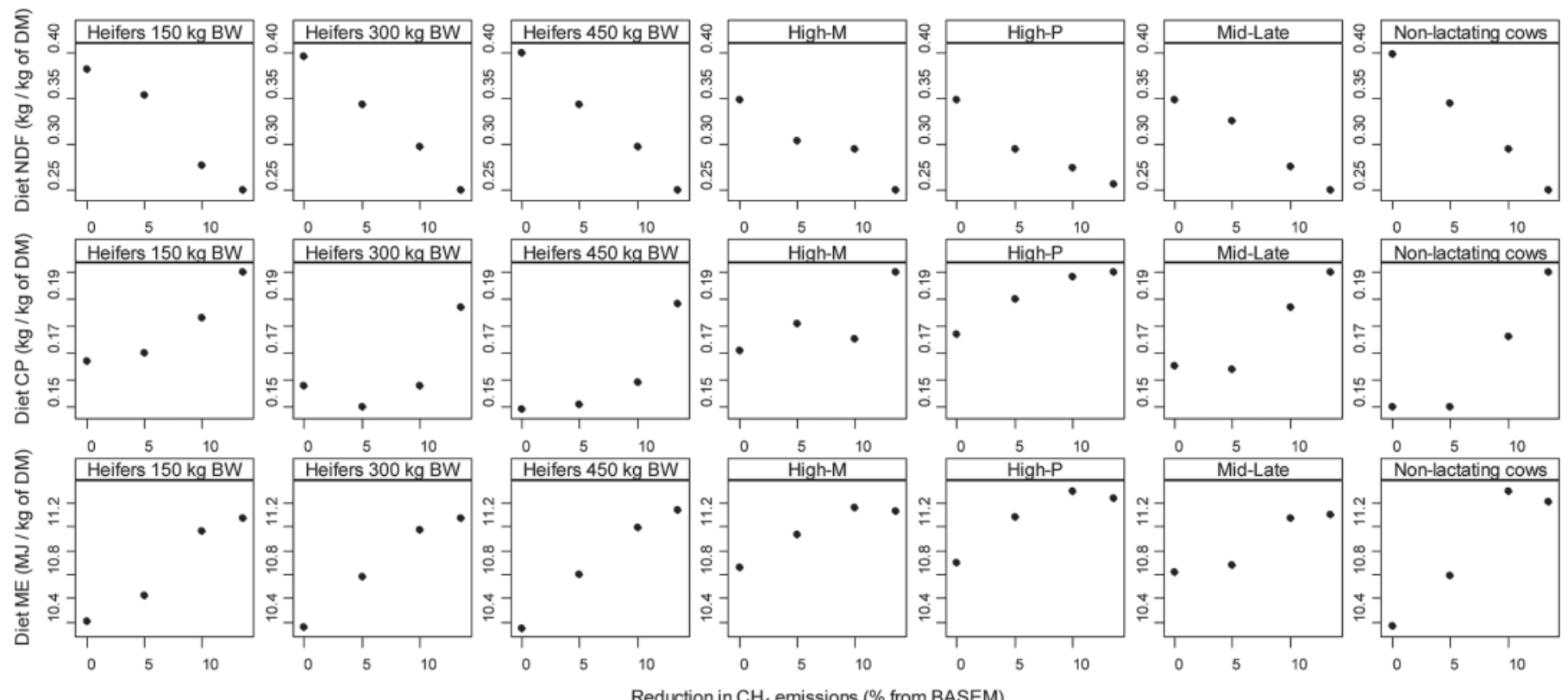

Figure 1. Proportion of NDF ( $\mathrm{kg}$ of NDF $/ \mathrm{kg}$ of DM), energetic density (MJ of ME $/ \mathrm{kg}$ of DM) and proportion of $\mathrm{CP}(\mathrm{kg}$ of $\mathrm{CP} / \mathrm{kg}$ of $\mathrm{DM}$ ) of diets formulated in the model with predetermined $\mathrm{CH}_{4}$ emission reductions (REDM) compared with respective reductions in $\mathrm{CH}_{4}$ emissions from the base model. High-M = high-producing multiparous lactating cow group, High-P = high-producing primiparous lactating cow group, Mid-Late $=$ the mid and late lactation cow group.

generated DMI values lower than values generated by BASEM. Selection of feeds lower in fiber and higher in $\mathrm{ME} / \mathrm{NE}_{\mathrm{L}}$ and $\mathrm{CP}$, when a $\mathrm{CH}_{4}$ constraint was used, led to a decrease in DMI. Nitrogen intake increased with the reduction in $\mathrm{CH}_{4}$ emissions (Table 6) because feeds with higher contents of protein were selected in diet formulations. However, for each level of $\mathrm{CH}_{4}$ emissions reduction, the increase in $\mathrm{N}$ intake differed among animal categories; for example, at 10\% reduc- tion in $\mathrm{CH}_{4}$ emissions from the BASEM, the mid to late lactating cow group was the category that had the largest proportional increase in $\mathrm{N}$ intake. On the other hand, at $13.5 \%$ reduction in $\mathrm{CH}_{4}$ emissions, nonlactating cows had the largest proportional increase in $\mathrm{N}$ intake. Potential environmental impacts and sensitivity analyses components (i.e., shadow prices, reduced costs and ranges) are model generated for each animal category because decision variables are indexed by animal

Table 4. Shadow prices of the maximum dietary protein and minimum dietary fiber constraints equations in the models with 5,10 , and $13.5 \%$ reductions of $\mathrm{CH}_{4}$ emissions (REDM5, REDM10, and REDM13.5, respectively) presented for each animal category ${ }^{1}$

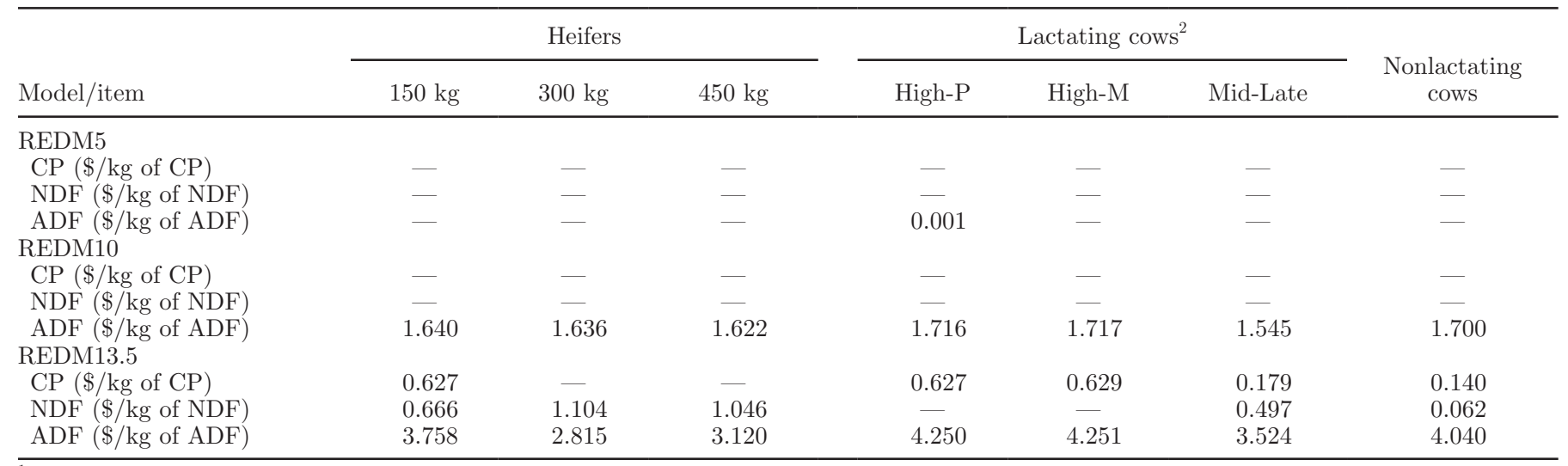

${ }^{1}$ Shadow prices of BASEM and TAXM are not presented because these constraints were not binding. Empty cells represent zero shadow price (not binding constraints).

${ }^{2}$ High-P = high-producing primiparous lactating cow group; High-M = high-producing multiparous lactating cow group; Mid-Late = mid and late lactating cow group. 
Table 5. Methane emissions (MJ of $\mathrm{CH}_{4} / 100 \mathrm{MJ}$ of ME intake) for the base model (BASEM) and for the models with 5, 10, and 13.5\% reductions of $\mathrm{CH}_{4}$ emissions (REDM5, REDM10, and REDM13.5, respectively) presented for each animal category ${ }^{1}$

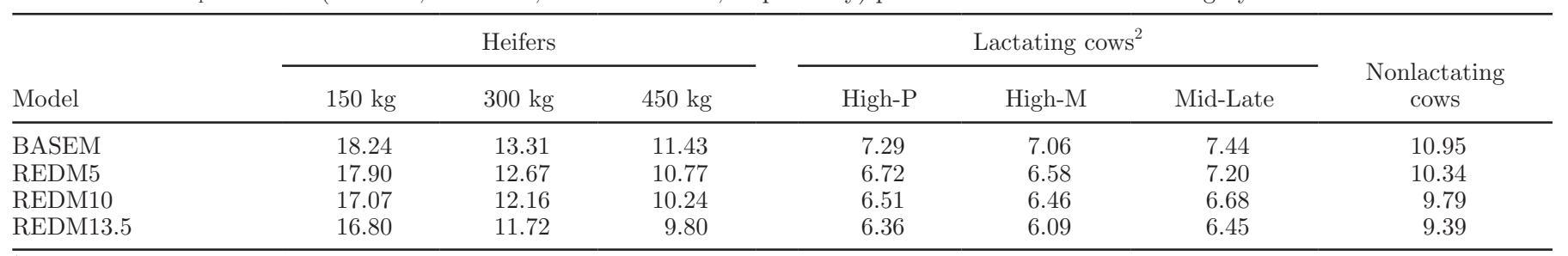

${ }^{1}$ Values represent individual animal daily emissions.

${ }^{2}$ High-P = high-producing primiparous lactating cow group; High-M = high-producing multiparous lactating cow group; Mid-Late = mid and late lactating cow group.

category. Therefore, the model enables identification of animal categories that are more sensitive to environmental policies and the ones in which $\mathrm{CH}_{4}$ emissions can be less expensively obtained.

Nitrogen and mineral excretions (Table 7) followed the same pattern as $\mathrm{N}$ and mineral intakes because those were calculated by mass balance and animal category retentions do not vary among models, with the exception of $\mathrm{N}$ retained in growth. Total $\mathrm{N}$ excretion was slightly greater $(0.4 \%)$ when $\mathrm{CH}_{4}$ emissions were reduced by $5 \%$. However, total $\mathrm{N}$ excretion increased by 3.1 and $16.5 \%$ when $\mathrm{CH}_{4}$ emissions were restricted by 10 and $13.5 \%$ of base levels, respectively. Phosphorus excretion was increased by 0.2 and $3.6 \%$ when $\mathrm{CH}_{4}$ emissions were reduced by 5 and $10 \%$ from the base (Table 7 ). Phosphorus excretion was also altered because $\mathrm{P}$ intake varied with different levels of $\mathrm{CH}_{4}$ emission reduction. To study the effects of environmental policies on feed selection and changes in mineral excretion, the intake of $\mathrm{P}$ and $\mathrm{K}$ was decomposed into total (including mineral sources) and intake from feeds (not including mineral sources). The intake from feeds was calculated by subtracting $\mathrm{P}$ and $\mathrm{K}$ intakes from mineral sources from the total $\mathrm{P}$ and $\mathrm{K}$ intakes. The increase in $\mathrm{P}$ intake from feeds did not always follow the same pattern as total $\mathrm{P}$ intake (i.e., $\mathrm{P}$ from feeds plus $\mathrm{P}$ from mineral sources), as reported in Table 6 . For example, at $5 \%$ reduction in $\mathrm{CH}_{4}$ emissions in $\mathrm{REDM}$, the total $\mathrm{P}$ intake was increased by $1.6 \%$ and $\mathrm{P}$ intake from feeds was reduced by $5.6 \%$. Therefore, this increase in $\mathrm{P}$ excretion cannot always be associated with increased intake of feeds with higher levels of $\mathrm{P}$, because part of the increased intake is from increased intake from a mineral source. Phosphorus was supplied as monocalcium phosphate, and calcium was usually more limiting than $\mathrm{P}$; therefore, the amount of monocalcium phosphate fed was usually dictated by the combination of Ca supply and requirements resulting in the excessive feeding of phosphorus. Phosphorus excretion decreased by $13.1 \%$ when $\mathrm{CH}_{4}$ was reduced by $13.5 \%$ from BASEM. This reduction of $\mathrm{P}$ excretion was not forced by the model structure and will not always occur with a reduction of NDF intake, depending on the feeds and mineral sources used in the formulation. A reduction of NDF intake should not be used as a way to reduce or predict $\mathrm{P}$ excretion because differences in available feeds and mineral sources may result in different $\mathrm{P}$ dietary proportions and intakes. Strategies to minimize $\mathrm{P}$ excretion were proposed by Kebreab et al. (2005), based on the dietary P supply at the requirement level and in the increase of $\mathrm{P}$ efficiency of utilization because $\mathrm{P}$ dietary supply above the requirement level usually is excreted in manure.

Potassium excretion decreased by 4.8 and $9.7 \%$ (Table 7) when $\mathrm{CH}_{4}$ emissions were reduced by 5 and

Table 6. Mineral, nitrogen, and DM intakes and $\mathrm{P}$ and $\mathrm{K}$ intake from feed consumption in the base model (BASEM) and in the models with 5, 10, and $13.5 \%$ reductions of $\mathrm{CH}_{4}$ emissions (REDM5, REDM10, and REDM13.5, respectively) ${ }^{1}$

\begin{tabular}{|c|c|c|c|c|}
\hline Item & BASEM & REDM5 & REDM10 & REDM13.5 \\
\hline DMI (kg) & 13,817 & 13,518 & 13,019 & 13,004 \\
\hline $\mathrm{N}$ intake $(\mathrm{kg})$ & 367 & 368 & 376 & 412 \\
\hline Na intake (kg) & 29 & 29 & 29 & 29 \\
\hline $\mathrm{P}$ intake $(\mathrm{kg})$ & 77 & 78 & 79 & 69 \\
\hline $\mathrm{P}$ intake from feeds ${ }^{2}(\mathrm{~kg})$ & 53 & 50 & 54 & 48 \\
\hline $\mathrm{K}$ intake $(\mathrm{kg})$ & 178 & 171 & 164 & 204 \\
\hline $\mathrm{K}$ intake from feeds ${ }^{2}(\mathrm{~kg})$ & 177 & 169 & 163 & 203 \\
\hline
\end{tabular}

${ }^{1}$ Results denote daily values for the 1000 animals herd. Phosphorus and potassium intakes from feed consumption denote total intake minus intake from mineral sources.

${ }^{2}$ Intake from feeds were calculated by total mineral intake minus intake from mineral sources. 
Table 7. Methane emissions, nitrogen and mineral excretion, manure production, and diet costs in the base model (BASEM) and in the models with 5, 10, and 13.5\% reductions of $\mathrm{CH}_{4}$ emissions (REDM5, REDM10, and REDM13.5, respectively $)^{1}$

\begin{tabular}{lcccc}
\hline Item & BASEM & REDM5 & REDM10 & REDM13.5 \\
\hline $\mathrm{CH}_{4}(\mathrm{MJ})$ & 12,595 & 11,966 & 11,336 & 10,895 \\
$\mathrm{CH}_{4}(\mathrm{t})$ & 0.2263 & 0.2150 & 0.2037 & 0.1958 \\
$\mathrm{~N}$ excretion $(\mathrm{kg})$ & 275.65 & 276.68 & 284.28 & 321.21 \\
K excretion $(\mathrm{kg})$ & 152.25 & 144.89 & 137.55 & 177.69 \\
$\mathrm{P}$ excretion $(\mathrm{kg})$ & 59.47 & 59.58 & 61.61 & 51.65 \\
Na excretion $(\mathrm{kg})$ & 17.35 & 17.35 & 17.35 & 17.37 \\
Manure $(\mathrm{t})$ & 42.18 & 41.25 & 39.79 & 39.72 \\
Diet costs $(\$)$ & 3,065 & 3,219 & 3,649 & 4,552 \\
\hline
\end{tabular}

${ }^{1}$ Results denote daily values for the 1,000-animal herd.

$10 \%$, respectively, because $\mathrm{K}$ intake decreased. However, the reduction in $\mathrm{K}$ excretion should not be associated with a general reduction in NDF intake and $\mathrm{CH}_{4}$ emissions because a different set of available feeds may produce different results, as discussed for $\mathrm{P}$ excretion. An increase of $16.7 \%$ in $\mathrm{K}$ excretion occurred with a $13.5 \%$ reduction in $\mathrm{CH}_{4}$ emissions due to an increased $\mathrm{K}$ intake. The increase in $\mathrm{K}$ intake was mainly a result of increase in $\mathrm{K}$ intake from feeds (Table 6). The increase in $\mathrm{K}$ intake by multiparous lactating cows was more pronounced than in other animal categories due to inclusion of higher levels of legume silage, which has a relatively high content of potassium.

Sodium intake and excretion remained relatively constant over models because Na was usually a limiting mineral and $\mathrm{Na}$ supplementation was usually required. In addition, $\mathrm{Na}$ was supplemented as sodium chloride, which was supplied on a quantity determined by animal needs. Therefore, from an environmental perspective, the utilization of more than one mineral source; for example, removing $\mathrm{Na}$ from the mineral premix and supplying it independently as salt, prevents feeding above the requirement level, minimizing $\mathrm{Na}$ excretion. On the other hand, in a fixed-composition mineral premix, the amount of premix fed is controlled by the most limiting mineral and all other minerals are fed in excess, as discussed for P intake. During model development, a model with a single mineral premix was solved and $\mathrm{Na}$ and $\mathrm{P}$ excretion were increased (results not shown) when $\mathrm{CH}_{4}$ emissions were limited because the amount of the premix fed was controlled by the most limiting mineral.

Some feeds have high contents of some minerals and, when formulating diets in a scenario in which excretion of these minerals could be an environmental concern, selection of feeds with a low content of these minerals will decrease excess excretion. The model structure can be used to set upper dietary limits of these feeds or minerals, with the use of equations in which determined feeds or minerals are restricted to specific amounts in the diet.
Manure production decreased by $2.2,5.7$, and $5.8 \%$ when $\mathrm{CH}_{4}$ emissions were restricted by 5,10 , and $13.5 \%$, mainly because of decreased DM intake and selection of feeds with higher ME concentrations. However, this decrease in manure production cannot be associated with a decrease in nitrate and mineral leaching because mineral excretion in manure usually increased with $\mathrm{CH}_{4}$ emission restrictions. The benefits of reduced manure production would be decreased costs of manure storage and management. Both TAXM and REDM could be used to assess how the dairy was affected by each type of environmental policy [i.e., atmosphere $\left(\mathrm{CH}_{4}\right)$ and water (mineral and $\mathrm{N}$ excretions and manure) impacts, costs (diets plus taxes), and changes in the combination of feeds in the diet and manure production], which can in total lead to changes in farm management decisions, to address the issues that define system sustainability.

Total herd $\mathrm{CH}_{4}$ emission was restricted in REDM, and the emission reductions differed among animal categories. Proportional reductions in $\mathrm{CH}_{4}$ emissions for nonlactating cows were usually larger than reductions from heifers and lactating animals due to the greater flexibility in model-driven diet changes, because nonlactating cows have lower nutrient requirements than growing and lactating animals and usually have relatively high proportions of dietary forage. This might suggest that nonlactating cows, with the inputs used in our model, may be more sensitive to reductions in $\mathrm{CH}_{4}$ emissions by dietary manipulation.

Diet costs were increased in REDM (Table 7), by 5.0, 19.1, and $48.5 \%$, when $\mathrm{CH}_{4}$ emissions were restricted by 5,10 , and $13.5 \%$, respectively. Total diet costs, in BASEM and when $\mathrm{CH}_{4}$ emissions were restricted by 5 , 10 and $13.5 \%$, were $\$ 3,065, \$ 3,219, \$ 3,649$, and $\$ 4,552$, respectively, for the entire herd of 1,000 animals. However, these results can be scaled to any size or composition of herd. Restrictions in $\mathrm{CH}_{4}$ emissions forced a decrease of dietary NDF, thereby decreasing modeldriven flexibility in finding less expensive diets. The level of $\mathrm{CH}_{4}$ reduction also had an effect on diet costs. Shadow prices of the $\mathrm{CH}_{4}$ emission reduction constraint 
equation in REDM represent the change in diet cost when the emission of $\mathrm{CH}_{4}$ was changed by 1 unit. In our study, these shadow prices represent how much diet costs would increase if $\mathrm{CH}_{4}$ emissions were decreased by 1 MJ (equivalent to $0.0179 \mathrm{~kg}$ ), or how much the diet costs would decrease if $\mathrm{CH}_{4}$ emissions were increased by 1 MJ. A plot (Figure 2) of these shadow prices was generated by reducing $\mathrm{CH}_{4}$ emissions from 1 to $13.5 \%$ to examine the role of the reduction of $\mathrm{CH}_{4}$ emissions in diet costs and in the resulting shadow prices. Shadow prices increased monotonically as $\mathrm{CH}_{4}$ emissions decreased from 1 to $13.5 \%$, ranging from 0.228 to $3.749 \$ /$ MJ (\$12,688 to $\$ 208,631 / \mathrm{t}$ of $\mathrm{CH}_{4}$ ) in this range of $\mathrm{CH}_{4}$ reduction. A large increase in shadow prices is observed in Figure 2 when $\mathrm{CH}_{4}$ emissions are reduced beyond the 9\% reduction level from the base model. At this level of reduction, minimum dietary ADF proportion starts to act as a binding constraint for all animal categories, and minimum dietary NDF from forage proportion starts to act as a binding constraint for mid to late lactation cows. Changes in shadow price values with a decrease in $\mathrm{CH}_{4}$ emissions were mainly due to the decrease in the dietary NDF content set by the $\mathrm{CH}_{4}$ constraint equation, forcing the model to select feeds with higher $\mathrm{ME} / \mathrm{NE}_{\mathrm{L}}$ and $\mathrm{CP}$ contents, which are usually the more expensive feeds.

Model shadow prices can be used to estimate the cost of reducing $1 \mathrm{t}$ of $\mathrm{CH}_{4}$ emissions and, therefore, can be used to estimate the costs of the $\mathrm{CO}_{2}$-equivalent tonne in the carbon credit market to force this predetermined reduction in $\mathrm{CH}_{4}$ emissions. These costs in our model ranged from $\$ 604$ to $\$ 9,935 / \mathrm{t}$ of $\mathrm{CO}_{2}$-equivalent (assuming a radiation reflection potential of 21 times the $\mathrm{CO}_{2}$ potential for $\mathrm{CH}_{4}$; i.e., costs of $\mathrm{CO}_{2}$-equivalent tonne were calculated dividing the $\mathrm{CH}_{4} \$ / \mathrm{t}$ by 21) when $\mathrm{CH}_{4}$ emissions were reduced by 1 to $13.5 \%$. These costs support results from TAXM, in which $\mathrm{CO}_{2}$-equivalent costs from $\$ 5$ to $\$ 250 / \mathrm{t}$ for the $\mathrm{CH}_{4}$ decision variable did not decrease $\mathrm{CH}_{4}$ emissions. Use of shadow price values generated by REDM could have an important role in determining the price of carbon credits in a carbon cap-trading scheme in an environmental policy. Any cap-and-trade system of carbon emissions trading will fix the amount of emissions that should be reduced by establishing a quantitative limit on total emissions, although the price of credits or allowances will be determined by market forces (Murray et al., 2009). Our model could be used to determine the price at which dairy producers could trade their $\mathrm{CH}_{4}$ emission allowances because REDM calculates the marginal costs of $\mathrm{CH}_{4}$ emission reductions. Indeed, the cost of reducing $1 \mathrm{t}$ of $\mathrm{CH}_{4}$ emitted in our study was much greater than the cost of the $\mathrm{CH}_{4}$ tonne in the 2 carbon credit markets used (CCX, 2010; ECX, 2010), suggesting that, for our herd, carbon credit prices at current levels would not be effective in inducing significant changes in dairy cattle diets. However, further analyses are required to examine the costs of reducing $\mathrm{CH}_{4}$ emissions in other pricing schemes because these shadow prices might be extremely sensitive to feed prices. Costs of reducing $\mathrm{N}$ and mineral excretion could also be generated if the model structure were set to restrict excretion of these elements, in the same manner that $\mathrm{CH}_{4}$ emissions were restricted in REDM. Therefore, the model will calculate mitigation costs for mineral and $\mathrm{N}$ excretions.

The targeted reduction in $\mathrm{CH}_{4}$ emissions increased $\mathrm{N}$ and mineral excretions, suggesting that environmental policies that focus on $\mathrm{CH}_{4}$ emission reduction in the atmosphere could increase $\mathrm{N}$ and mineral releases in manure in terrestrial sites and possibly aerosol $\mathrm{N}$ and nitrous oxide emissions, creating a tradeoff between reduction of $\mathrm{CH}_{4}$ and consequently an increase in the emission of another GHG, nitrous oxide. Therefore, environmental policies aimed at dairies should be developed with a broader perspective, realizing that reducing $\mathrm{CH}_{4}$ emissions by dietary manipulation could be associated with undesirable increases in $\mathrm{N}$ and mineral excretions. Moreover, prices of current carbon credit markets were too low to decrease $\mathrm{CH}_{4}$ emissions substantially. Shadow prices from REDM suggest that costs of the $\mathrm{CO}_{2}$ equivalent allowances need to be much higher if they are to alter diet formulation and decrease $\mathrm{CH}_{4}$ emissions of our hypothetical dairy cattle

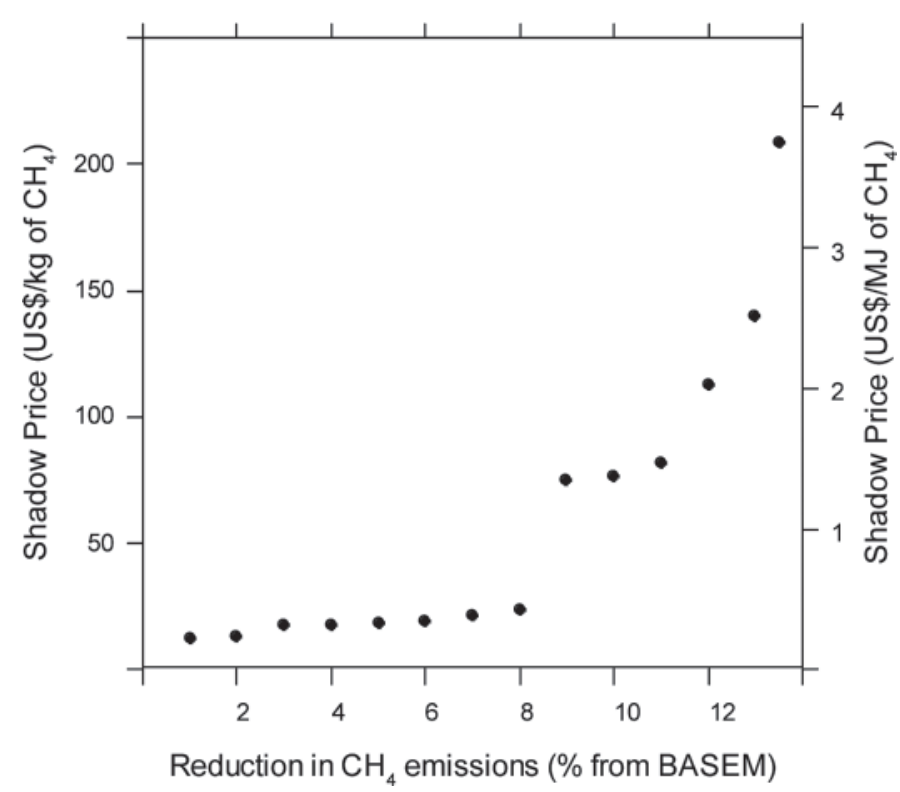

Figure 2. Shadow prices of the $\mathrm{CH}_{4}$ restriction constraint of the model with predetermined $\mathrm{CH}_{4}$ emission reductions (REDM; $\$ / \mathrm{kg}$ of $\mathrm{CH}_{4}$ ) compared with respective reductions in $\mathrm{CH}_{4}$ emissions from the base model (13.5\% was the maximum reduction in $\mathrm{CH}_{4}$ emissions for a feasible model solution). 
herd. Use of shadow price information can be useful to dairy producers in determining the trading value of their environmental impact allowances and, overall, to decide if they should manipulate animal diets to decrease $\mathrm{CH}_{4}$ emissions or if the allowances are profitable to be bought in a cap-and-trade policy scenario. Model shadow prices also demonstrate that, with the adopted model inputs, $\mathrm{CH}_{4}$ mitigation strategies through diet manipulation would be extremely expensive for dairy producers. For example, the average $\mathrm{CH}_{4}$ production for lactating cows at BASEM was 16.7 MJ. If we assume that a $10 \%$ reduction in $\mathrm{CH}_{4}$ emissions is established as policy, the $\mathrm{CH}_{4}$ reduction would be $1.67 \mathrm{MJ}$ (or $30 \mathrm{~g}$ of $\mathrm{CH}_{4}$ ) per cow per day. Multiplying 1.67 MJ by the shadow price of $\$ 1.379 / \mathrm{MJ}$, at $10 \%$ reduction $\mathrm{CH}_{4}$, the daily cost of dietary manipulation to meet the target emission would be $\$ 2.3 /$ cow. This cost represents approximately $47 \%$ of daily dietary costs $(\$ 4.9 /$ cow per day) of the average lactating cow at BASEM. Although these may be an overestimate of actual costs of such a policy, the values suggest relatively high policy costs that would either be passed on to consumers or cause some dairy operations to go out of business or locate in areas out of reach of the policy.

The use of this conceptual model structure (TAXM and REDM) is flexible, as feeds, feed compositions, nutrient requirements, prediction equations, and operation size and type can be altered. In addition, other restrictions in environmental impact could be chosen according to constraints or the minimization objective, such as minimizing the amount of mineral excreted along with diet costs. This conceptual model can be easily implemented in the existing diet formulation and whole-farm simulation models because these models usually have optimization algorithms. In our study, only $\mathrm{CH}_{4}$ emissions were restricted, but $\mathrm{N}$ and mineral excretion could also be restricted in a scenario in which surface water contamination is a major concern. Model sensitivity analysis could be used to predict costs of reducing potential environmental impacts due to livestock production. This model framework also enables connections between food production and potential environmental impacts of dairy cattle farming to be established, and could be a useful tool in studying scenarios in which more sustainable dairy production systems are required.

\section{CONCLUSIONS}

The TAXM model represented a scenario in which dairy producers were taxed on the amount of $\mathrm{CH}_{4}$ emitted, or alternatively, were required to purchase emissions permits from a permit market. Current prices of the $\mathrm{CO}_{2}$ equivalent in the carbon credit market, which were used as the hypothetical $\mathrm{CH}_{4}$ taxes, had no measurable effect in reducing $\mathrm{CH}_{4}$ through diet manipulation in our hypothetical system. Similar results were found by REDM, which reduced predetermined amounts of $\mathrm{CH}_{4}$ emissions from the base model. Shadow prices of the $\mathrm{CH}_{4}$ reduction constraint were much higher than the relative costs of the carbon credits in the current carbon market. In our hypothetical herd, reducing $\mathrm{CH}_{4}$ emissions with a relatively stringent emission reduction target would alter feed selection away from forages and toward low-NDF grains and protein products, thereby altering diet costs and $\mathrm{CH}_{4}$ emissions as well as $\mathrm{N}$ and mineral excretion. Marginal costs of reducing $\mathrm{CH}_{4}$ through dietary manipulation were extremely high in our hypothetical herd, suggesting that the hypothetical policies might lead to an increase in milk prices and a substantive reduction in the income over feed costs of dairy producers. Generally, N excretions were increased with a reduction in $\mathrm{CH}_{4}$ emissions, and $\mathrm{P}$ and $\mathrm{K}$ excretions fluctuated with different levels of $\mathrm{CH}_{4}$ emission reductions. These results are based on the feeds, herd, and prices (i.e., model inputs) adopted in this study, and, before our findings are used in policy development, results from this model should be generated from several schemes of inputs. The model can be used to examine system sustainability because its structure can be used in decision-making processes in management, evaluation, and minimization of production costs, and in the evaluation of potential environmental impacts of the dairy system.

\section{ACKNOWLEDGMENTS}

Research was supported by the W. K. Kellogg Endowment, USDA NIFA Multistate Research Project NC-1040. We gratefully acknowledge the infrastructure support of the Department of Animal Science, College of Agricultural and Environmental Sciences, and the California Agricultural Experiment Station of the University of California, Davis. The authors thank James Tully (Pine Creek Nutrition Service, Denair, CA), Theo Lykos (Lykos Nutritional Services, Fresno, CA), Randy Bowen (Valley Nutrition, Visalia, CA), and Doug DeGroff (Diversified Dairy Solutions LLC, Visalia, CA) for helpful comments and suggestions.

\section{REFERENCES}

Agricultural and Food Research Council (AFRC). 1993. Energy and Protein Requirements of Ruminants. CAB International, Wallingford, UK.

Beever, D. E., S. B. Cammell, J. D. Sutton, M. C. Spooner, M. J. Haines, and J. I. Harland. 1989. The effect of concentrate type on energy utilization in lactating cows. Proc. 11th Symp. Energy Metabolism. EAAP Publication No. 43. EAAP, Wageningen, the Netherlands. 
Brooke, A., D. Kendrick, A. Meeraus, and R. Raman. 2008. GAMS: A User's Guide. Release 2.50. The Scientific Press, Redwood City, CA.

Capper, J. L., R. A. Cady, and D. E. Bauman. 2009. The environmental impact of dairy production: 1944 compared with 2007. J. Anim. Sci. 87:2160-2167.

Cerri, C. E., S. M. F. Maia, M. V. Galdos, C. E. P. Cerri, B. J. Feigl, and M. Bernoux. 2009. Brazilian greenhouse gas emissions: The importance of agriculture and livestock. Sci. Agric. 66:831-843.

Chicago Climate Exchange (CCX). 2010. Greenhouse gas reduction and trading system. Accessed Dec. 07, 2010. http://www.chicagoclimatex.com.

CSIRO (Commonwealth Scientific and Industrial Research Organization). 1990. Feeding standards for Australian livestock ruminants. CSIRO, Melbourne, Australia.

Edmonds, J., S. H. Kim, C. N. MacCracken, R. D. Sands, and M. Wise. 1997. Return to 1990: The cost of mitigating United States carbon emissions in the post-2000 period. Report No. PNNL11819, Pacific Northwest National Laboratory, Washington, DC.

Ellis, J. L., E. Kebreab, N. E. Odongo, B. W. McBride, E. K. Okine, and J. France. 2007. Prediction of methane production from dairy and beef cattle. J. Dairy Sci. 90:3456-3466.

EPA (Environmental Protection Agency). 2003. National pollutant discharge elimination system permit regulation and effluent limitations, guidelines and standards for concentrated animal feeding operations (CAFOs). Final rule. Fed. Regist. 68:7176-7227.

EPA (Environmental Protection Agency). 2011. Inventory of U.S. Greenhouse Gas Emissions and Sinks: 1990-2009. EPA 430-R-11005. Environmental Protection Agency, Washington, DC.

European Climate Exchange (ECX). 2010. European carbon trading institution. Accessed Dec. 07, 2010. http://www.ecx.eu.

Fadel, J. G. 2010. Feed-to-food conversion: Contributions to society. 1:1 Pages 422-426 in Encyclopedia of Animal Science. 2nd ed. W. Pond and A. Bell, ed. Taylor \& Francis, New York, NY.

FAO. 2006. Livestock's Long Shadow: Environmental Issues and Options. Food and Agriculture Organization of the United Nations (FAO), Rome, Italy.

Institute National de la Recherche Agronomique (INRA). 1989. Ruminant Nutrition. Libbey Eurotext, Montrouge, France.

IPCC (Intergovernmental Panel on Climate Change). 1996. Climate Change 1995: The Science of Climate Change. Intergovernmental
Panel on Climate Change. J. T. Houghton, L. G. Meira Filho, B. A. Callander, N. Harris, A. Kattenberg, and K. Maskell, ed. Cambridge University Press, Cambridge, U.K.

James, T., D. Meyer, E. Esparza, E. J. DePeters, and H. Perez-Monti. 1999. Effects of dietary nitrogen manipulation on ammonia volatilization from manure from Holstein heifers. J. Dairy Sci. 82:2430-2439.

Kebreab, E., J. France, J. D. Sutton, L. A. Crompton, and D. E. Beever. 2005. Effect of energy and protein supplementation on phosphorus utilization in lactating dairy cows. J. Anim. Feed Sci. 14:63-77.

Kebreab, E., K. A. Johnson, S. L. Archibeque, D. Pape, and T. Wirth. 2008. Model for estimating enteric methane emissions from United States dairy and feedlot cattle. J. Anim. Sci. 86:2738-2748.

Kebreab, E., A. Strathe, J. Fadel, L. Moraes, and J. France. 2010 Impact of dietary manipulation on nutrient flows and greenhouse gas emissions in cattle. R. Bras. Zootec. 39:458-464.

Moe, P. W., and H. F. Tyrrell. 1979. Methane production in dairy cows. J. Dairy Sci. 62:1583-1586.

Morse, D., H. H. Head, and C. J. Wilcox. 1992. Disappearance of phosphorous in phytate from concentrates in vitro from rations fed to lactating dairy cows. J. Dairy Sci. 75:1979-1986.

Murray, B. C., R. G. Newell, and W. Pizer. 2009. Balancing cost and emissions certainty: An allowance reserve for cap-and-trade. Rev. Environ. Econ. Policy 3:84-103.

NRC. 2001. Nutrient Requirements of Dairy Cattle. 7th ed. National Academy Press, Washington, DC.

Nennich, T. D., J. H. Harrison, L. M. VanWieringen, D. Meyer, A. J. Heinrichs, W. P. Weiss, N. R. St-Pierre, R. L. Kincaid, D. L. Davidson, and E. Block. 2005. Prediction of manure and nutrient excretion from dairy cattle. J. Dairy Sci. 88:3721-3733.

Penn State Feed Price List. 2011. Pennsylvania State University Cooperative Extension. Accessed Sep. 5, 2011. http://www.das.psu. edu/research-extension/dairy/pdf/feedprices.pdf.

Tamminga, S. 1992. Nutrition management of dairy cows as a contribution to pollution control. J. Dairy Sci. 75:345-357.

Weitzman, M. L. 1974. Prices vs. quantities. Rev. Econ. Stud. 41:477-491. 


\section{APPENDIX}

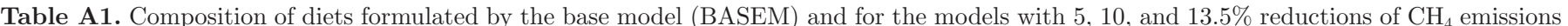
(REDM5, REDM10, and REDM13.5, respectively) ${ }^{1}$

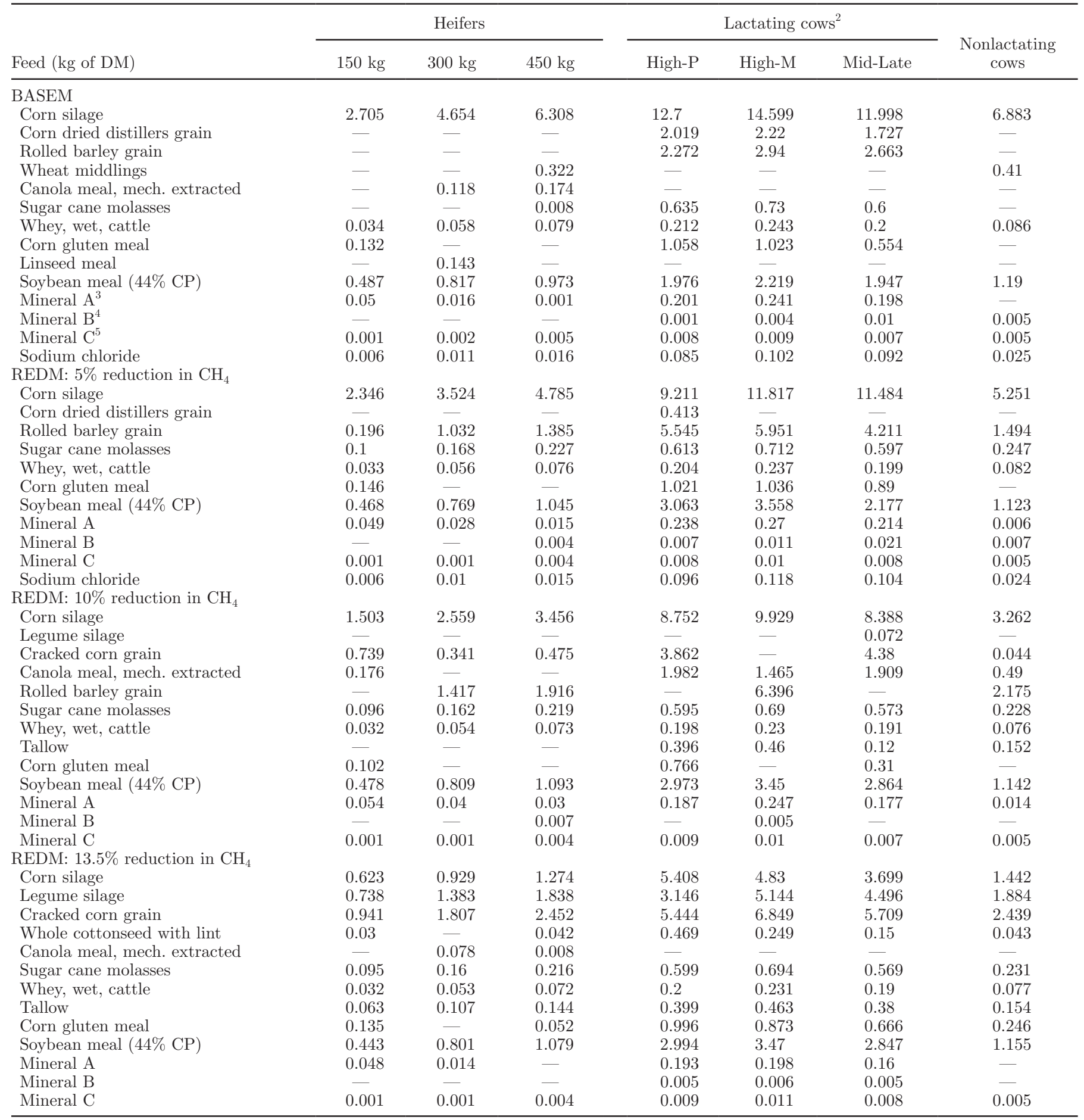

${ }^{1}$ Values refer to diet for one animal.

${ }^{2}$ High-P = high-producing primiparous lactating cow group; High-M = high-producing multiparous lactating cow group; Mid-Late = mid and late lactating cow group.

${ }^{3}$ Contained $15 \% \mathrm{Ca}$ and $21 \% \mathrm{P}$.

${ }^{4}$ Contained $22.5 \% \mathrm{~S}, 18 \% \mathrm{~K}$, and $11.5 \% \mathrm{Mg}$.

${ }^{5}$ Contained $3.75 \% \mathrm{Zn}, 3 \% \mathrm{Mn}, 1.25 \% \mathrm{Cu}$, and $0.25 \%$ Co. 